\title{
Ultrasonography of the conceptus development from days 15 to 60 of pregnancy in non-cyclic recipient mares
}

\author{
Ultrassonografia do desenvolvimento do concepto entre 15 e 60 dias de gestação em éguas \\ receptoras acíclicas
}

\author{
Elisa Sant'Anna Monteiro da Silva ${ }^{\mathrm{I}}$ José Carlos de Figueiredo Pantoja ${ }^{\text {II }}$ \\ José Nicolau Próspero Puoli Filho ${ }^{\mathrm{III}}$ Cezinande Meira $^{\mathrm{I}^{*}}$
}

\begin{abstract}
The present study evaluated the development of equine conceptus transferred to non-cyclic recipient mares treated with altrenogest. Twenty four mares were used as embryo recipients during the ovulatory phase (Control group; $n=8$ ) or anestrus/transitional phases (Altrenogest group; $n=16$ ) and were evaluated by transrectal ultrasonography, at five day intervals, to monitor the development of embryonic vesicles from 15 to 45 days of pregnancy and embryo proper/fetus from 20 to 60 days. Embryonic vesicle's features such as shape, embryo location within the vesicle and umbilical cord development were similar between cyclic and non-cyclic recipient mares. The embryonic vesicle and embryo proper/fetus growth was significant $(P<0.05)$ between 15 and 60 days of gestation in Altrenogest and Control groups, except for days 20 to 30, where embryonic vesicle growth decrease was observed $(P>0.05)$. The embryonic vesicle and embryo proper/ fetus growth was similar $(P>0.05)$ when gestational days were compared between groups. The similarity in conceptus growth between cyclic and non-cyclic recipient mares during early pregnancy indicates that the uterine environment of non-cyclic recipient mares treated with progestins provides similar conditions for the development of transferred embryos.
\end{abstract}

Key words: altrenogest, non-cyclic recipient mares, embryonic vesicle, embryo proper, fetus.

\section{RESUMO}

$O$ presente trabalho avaliou o desenvolvimento de conceptos equinos transferidos para éguas receptoras aciclicas, tratadas com altrenogest. Vinte e quatro receptoras gestantes por transferência de embrião durante a fase cíclica (grupo Controle; $n=8$ ) ou acíclica (grupo Altrenogest; $n=16$ ) foram avaliadas por meio de ultrassonografia transretal, a cada cinco dias, para monitorar o desenvolvimento da vesícula embrionária entre 15 e 45 dias de gestação e embrião/feto dos 20 aos 60 dias. As características da vesícula embrionária quanto ao formato, localização do embrião dentro da vesícula e formação do cordão umbilical foram similares em receptoras cíclicas e acíclicas. $O$ crescimento $d a$ vesícula embrionária e embrião/feto foi significativo $(P<0,05)$ entre 15 e 60 dias de gestação nos grupos Altrenogest e Controle, com exceção dos dias 20 a 30, em que redução no crescimento da vesícula embrionária foi observada $(P>0,05)$. O crescimento da vesícula embrionária e embrião/feto também foi similar $(P>0,05)$ entre grupos nos diferentes dias de gestação. A similaridade no crescimento do concepto entre éguas receptoras cíclicas e acíclicas durante o início da gestação indica que o ambiente uterino de receptoras acíclicas, mantidas com progestágeno, oferece condições similares para o desenvolvimento de um embrião transferido.

Palavras-chave: altrenogest, éguas receptoras aciclicas, vesícula embrionária, embrião, feto.

\section{INTRODUCTION}

The use of cyclic and non-cyclic recipient mares in embryo transfer (ET) programs is a well established practice in equine reproduction. However, there are limiting factors in these ET programs, such as reduced number and quality of recipient mares during the breeding season, especially during the spring transitional phase.

Aiming to increase donor mares' productivity throughout the year, administration of hormonal treatments can be applied to enable establishment and maintenance of pregnancy in non-

'Departamento de Reprodução Animal e Radiologia Veterinária, Faculdade de Medicina Veterinária e Zootecnia (FMVZ), Universidade Estadual Paulista (UNESP), 18618-970, Botucatu, SP, Brasil. E-mail: meira@fmvz.unesp.br. *Corresponding author.

"Departamento de Higiene Veterinária e Saúde Pública, FMVZ, UNESP, Botucatu, SP, Brasil.

IIIDepartamento de Produção Animal, FMVZ, UNESP, Botucatu, SP, Brasil. 
cyclic mares, by the administration of exogenous steroidal hormones (ROCHA FILHO et al., 2004; SILVA et al., 2014). Most of the studies demonstrate that pregnancy and early embryonic death rates of non-cyclic recipient mares are similar to those of cyclic recipients, and thus can be successfully used in ET programs (CARNEVALE et al., 2000; ROCHA FILHO et al., 2004; GRECO et al., 2012; SILVA et al., 2014). In addition, the use of non-cyclic recipient mares is an advantageous alternative to horse owners and veterinarians, since it enables the anticipation and/or prolongation of the breeding season (GRECO et al., 2012), eliminates the need for synchrony of ovulation between donor and recipient and reduces the number of recipients per donor (MCKINNON et al., 1988).

The implementation of transrectal ultrasonography has revolutionized equine pregnancy diagnosis and monitoring in equine breeding programs. In this species, the close proximity of the uterine wall to the rectal wall and the relative large size of the fluid-filled embryonic vesicle contribute to early pregnancy diagnosis and monitoring of the conceptus development using ultrasonography (GINTHER, 1995).

The equine conceptus growth profile during early gestation was studied by GINTHER (1995), who produced a detailed description of embryonic and fetal growth from days nine to 45 after ovulation by using B-mode ultrasonography. The knowledge of a normal growth pattern for the equine conceptus development during early pregnancy allows embryo/fetal age prediction when performing pregnancy diagnosis, as well as aids in the detection of abnormalities which could indicate the ocurrence of embryonic loss.

Currently, with the large spread of embryo transfer throughout Brasil and other countries, the use of non-cyclic recipient mares has become a common routine to increase recipients offer. However, there are no studies describing the pattern of embryonic and fetal development during early gestation in non-cyclic recipient mares treated with exogenous progestins to maintain pregnancy. To test the hypothesis that morphological ultrasound features and growth profile of conceptus development in non-cyclic recipient mares are similar to those found in cyclic recipients or mated/inseminated mares, the aims of this study were to describe and compare embryo and fetal development, from 15 to 60 days of age, of donor mares' conceptuses transferred to altrenogest treated non-cyclic recipient or non-treated cyclic recipient mares.

\section{MATERIAL AND METHODS}

The study was carried out between July and February in a commercial breeding farm (Fazenda São Sebastião, Mira Estrela, SP, Brazil, latitude $19^{\circ}$ $58^{\prime} 46^{\prime \prime}$ and longitude $\left.50^{\circ} 08^{\prime} 14^{\prime \prime}\right)$. Twenty four cross-bred pregnant recipient mares, ranging in age from four to 15 years and weighing between 350 and $450 \mathrm{~kg}$, were assigned to the experiment. Nutritional requirements were provided by using a diet based on hay, concentrate, mineral supplementation and water ad libitum.

Cyclic and non-cyclic mares (anestrus and transitional) were selected to be part of the experimental groups. Anestrus mares were characterized by the presence of follicles $<15 \mathrm{~mm}$, absence of a corpus luteum (CL) and lack of follicular growth for at least 21 days. Transitional mares were characterized by the presence of at least three follicles with $\geq 20 \mathrm{~mm}$ and absence of a $\mathrm{CL}$; and cyclic mares were those showing regular estrous cycle and ovulatory follicles. Mares were assigned to Altrenogest group $(n=16)$, consisting of non-cyclic recipient mares in anestrus $(n=9)$ or transition $(n=7)$, treated with altrenogest to establish and maintain gestation; or Control group, consisting of non-treated cyclic recipient mares.

After detection of a $35 \mathrm{~mm}$ follicle and uterine edema, ovulation was induced in donor mares with 2500IU of hCG (Vetecor $^{\circledR}$, Hertape Calier). Mares were inseminated with fresh or cooled semen from different stallions of known fertility 24 hours after hCG administration. Uterine flushes were done eight days post ovulation by non-surgical procedure (SQUIRES et al., 2003) using 4L of Ringer Lactate solution $\left(\right.$ Sanobiol $\left.^{\circledR}\right)$. After identification, the embryos were washed and maintained in culture medium (TQC Holding Plus ${ }^{\circledR}$ Nutricell) and were subsequently transferred to recipient mares.

Non-cyclic recipient mares were treated with a single dose of estradiol benzoate $\left(2.5 \mathrm{mg} \mathrm{kg}^{-1}\right.$, i.v.; Estrogin ${ }^{\circledR}$, Farmavet), one to three days after donor ovulation. The mares were examined by ultrasound one day after treatment to evaluate the presence of uterine edema. Once edema was confirmed, mares were supplemented with $33 \mathrm{mg}(15 \mathrm{~mL})$ of altrenogest, according to the manufacturer's recommendation (22-44mg day ${ }^{-1}$ mare $^{-1}$, p.o.; Progestal ${ }^{\circledR}$, ProSer, Argentina), every 24 hours. Embryo transfers were performed between days 4 and 6 after beginning of altrenogest treatment in the non-cyclic recipient mares (Altrenogest group) and between days 4 and 6 after ovulation in control mares. If pregnancy was 
confirmed, altrenogest administration was maintained daily until day 120 for group Altrenogest.

Mares were examined by transrectal B-mode ultrasound (Mindray ${ }^{\circledR}$ DP-3300Vet) using a 5 and $7,5 \mathrm{MHz}$ linear transducer for evaluating recipients uterine and ovarian conditions, as well as pregnancy diagnosis and maintenance on days 15 , $20,25,30,35,40,45,50,55$ and 60. Supplementary corpora lutea (SCL) formation was also monitored from day 35 of pregnancy onwards to evaluate a potential effect on fetal growth in Altrenogest group.

Measurements of the embryonic vesicle (15 to 45 days of gestation), embryo proper (20 to 35 days of pregnancy) and subsequently fetus (40 to 60 days) were performed every five days. The diameter $(\mathrm{mm})$ of the embryonic vesicle was defined as the mean height and width of the vesicle's ultrasound image and the embryo proper/fetus was measured by the crown-rump length.

A repeated measures model was used to compare the mean $( \pm \mathrm{SE})$ of the embryonic vesicle diameter $(\mathrm{mm})$ or embryo proper/fetus length $(\mathrm{mm})$ between groups (treatment or control) and days of measurement. An auto-regressive covariance structure resulted in the best fit for modeling the correlation between observations within the same mare. The Tukey's test was used to adjust the P-values that resulted from multiple comparisons. The analysis was performed with PROC MIXED (SAS INSTITUTE, 2009) at a significance level of 0.05 .

\section{RESULTS}

From a total of twenty four mares with positive pregnancy diagnosis at 15 days, twenty one remained pregnant until the end of the experiment (Day 60). Three embryonic losses (12.5\%) were detected between 21 and 25 days of gestation, with two cases (12.5\%) in the Altrenogest group and one $(12.5 \%)$ in the Control group $(\mathrm{P}>0.05)$.

The shape of the embryonic vesicle was spherical in all mares at 15 days of pregnancy, (Figure 1A), whereas at 20 days the shape was irregular, mostly at the dorsal region of the vesicle (Figure 1B). In the three mares in which embryonic loss was detected, the vesicle's shape remained spherical at 20 days of gestation. The embryo proper, characterized as an echogenic spot in the ventral region of the vesicle, was detected at day 20 in four out of seven mares that remained pregnant from Control group and in 12 out of 14 mares that maintained gestation from Altrenogest group.
At 25 days of pregnancy, the embryo, which was still located in the ventral portion of the vesicle, was detected in all mares from both groups and a developing allantoic sac was detected ventral to the embryo (Figure 1C). At 30 days, the embryo proper was located in the center of the vesicle, separating the growing allantoic sac from the regressing yolk sac (Figure 1D). At 35 days of gestation, the embryo proper was found in the dorsal region of the vesicle (Figure 1E) and on day 40, the umbilical cord formation was detected (Figure 1F). On the subsequent evaluations (days 45, 50, 55 and 60), the fetus was found in the ventral aspect of the vesicle, showing high mobility within the allantoic sac. There were no differences between groups regarding the morphological features of the embryonic vesicle, embryo proper/fetus, conceptus location inside the vesicle and umbilical cord formation, based on ultrasound examination on the evaluated days.

When the embryonic vesicle growth was assessed and the variable day was compared between groups, there were no differences between the averages of Altrenogest and Control group on the evaluated days of pregnancy $(\mathrm{P}>0.05)$. The diameter of the vesicle increased significantly $(\mathrm{P}<0.05)$ in both groups between 15 and 45 days of gestation, except for the period between 20 and 30 days, where a growth reduction was observed (Figure 2A).

For embryo proper/fetus, there were no differences detected between the averages of treated and control groups on the different days of gestation $(\mathrm{P}>0.05)$. In both groups, a similar significant growth $(\mathrm{P}<0.05)$ was observed between 20 and 60 days of pregnancy (Figure $2 \mathrm{~B})$.

The SCL formation was detected in all Control group mares between 40 and 45 days of pregnancy and in four mares from Altrenogest group between days 40 and 60 of gestation. There were no differences on conceptus growth between altrenogest treated mares that developed SCL and those that did not $(\mathrm{P}>0.05)$.

\section{DISCUSSION}

The use of non-cyclic recipient mares in ET programs and their pregnancy rates have been described in the literature (CARNEVALE et al., 2000; GRECO et al., 2012; SILVA et al., 2014). However, there are no reports on the developmental pattern of conceptuses transferred to these recipients during early pregnancy.

In mated or inseminated pregnant mares, the incidence of embryonic loss ranges from $5 \%$ to 


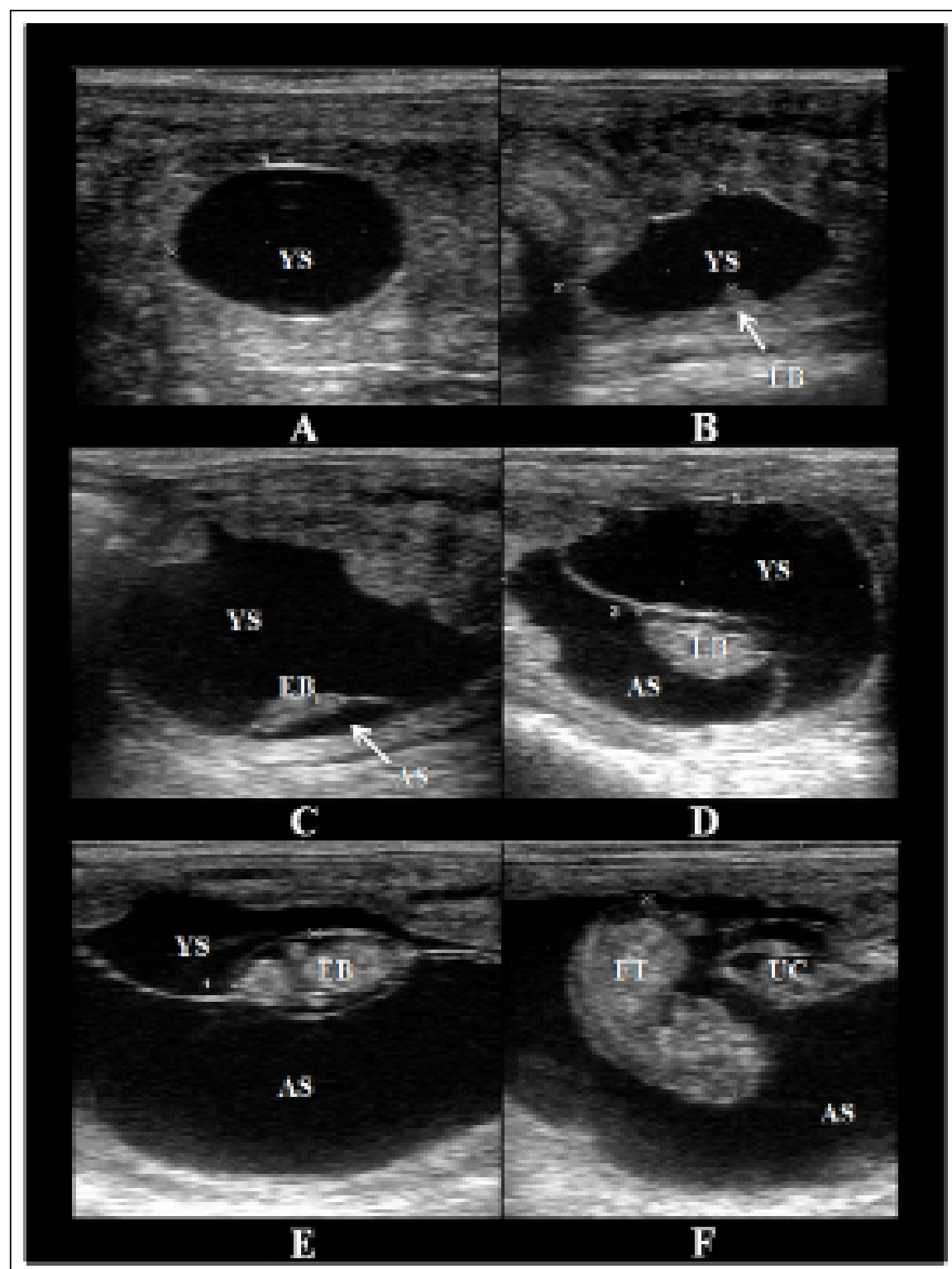

Figure 1 - Ultrasonography images $(7.5 \mathrm{MHz})$ of conceptuses from non-cyclic recipient mares at different gestational days. A) Embryonic vesicle consisting of a yolk sac (YS) at 15 days of gestation; B) embryonic vesicle showing irregularities at the dorsal region and an embryo proper (EB) detected as an echogenic spot at the ventral region of the vesicle, at 20 days of pregnancy. C) Embryo proper (EB) aging 25 days in the embryonic vesicle and the development of the allantoic sac (AS) at the ventral region of the embryo. D) Embryo proper (EB) located at the center of the embryonic vesicle at 30 days, separating the allantoic sac (AS) from the yolk sac (YS). E) At 35 days of gestation, embryo proper (EB) visualized at the dorsal region of the vesicle; F) and at 45 days, a fetus (FT) attached to the umbilical cord (UC).

$24 \%$ between 10 and 60 days after ovulation (BALL, 1988; VANDERWALL, 2008). When the incidence of embryonic loss was evaluated by CARNEVALE et al. (2000) in cyclic recipient mares, the authors found a $16 \%$ loss between 12 and 40 days of gestation, with the highest incidence detected between 17 and 25 days, as observed in the present study. Therefore, the embryonic loss rates in non-cyclic recipient mares found in this study are similar to those of cyclic recipients and mated or inseminated pregnant mares.

The spherical shape of the embryonic vesicle observed at 15 days is well documented in 


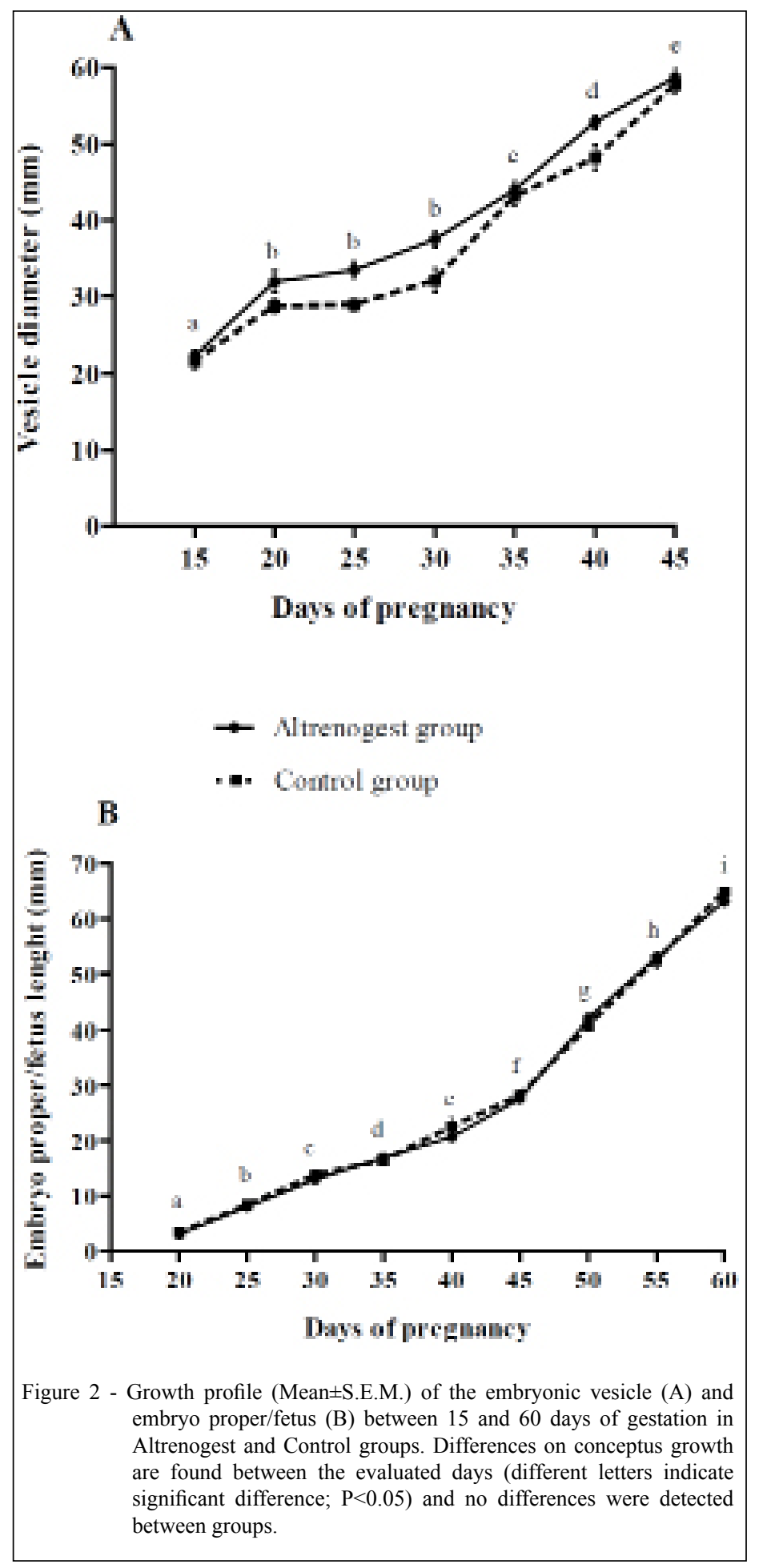

the literature (GINTHER, 1992; GINTHER, 1995; SILVA \& GINTHER, 2006) and is attributed to the glycoprotein capsule that surrounds the vesicle, providing resilience to the embryo during the intrauterine mobility phase (days six to 16 after ovulation), necessary for the maternal recognition of pregnancy (BETTERIDGE, 1989).

Irregularities in the dorsal region of the embryonic vesicle were detected at day 20 of pregnancy in all mares that maintained gestation 
until the last evaluation. These irregularities are due to an increased uterine turgidity and to a thickening of the dorsal uterine wall (GINTHER, 1998). Thickening of the dorsal endometrial wall or mesometrial orientation of the uterus (position of the mesometrial attachment to the uterus) occurs close to the point of entry of blood vessels to the uterine horns (SILVA \& GINTHER, 2006). In this way, the dorsal thickening may be considered preparatory for the umbilical cord attachment to the uterine mesometrial orientation (GINTHER, 1998). In addition, GASTAL et al. (1998) reported the use of a uterine tone inhibitor (clenbuterol) for mares, which made the vesicle shape become more spherical at 19 days of pregnancy. In the present study, the embryonic vesicle shape remained spherical at 20 days in the three mares in which embryonic loss occurred, possibly due to a uterine tone decrease or deficiency, although the embryonic loss causes have not been investigated. The spherical shape of the embryonic vesicle associated with a poor uterine tone at the abovementioned gestational phase may be an indicator of imminent embryonic death.

According to GINTHER (1983), the embryo proper can be detected in the embryonic vesicle between days 19 and 22 of gestation using B-mode ultrasonography. In a color-Doppler study, SILVA \& GINTHER (2006) detected the embryos earlier, between 17 and 20 days after ovulation, due to a better resolution of the B-mode ultrasound combined with the color-Doppler function. In the present study, embryos were not observed at 20 days of pregnancy in $23.8 \%(n=5)$ of the mares that maintained gestation until de end of the evaluations and no embryos were observed in the mares in which the embryonic vesicles remained spherical at 20 days. Although the embryo proper has not been detected in a few embryonic vesicles with irregularities on the dorsal region at 20 days of gestation, it is likely that these embryos would have been identified at 21 or 22 days if the ultrasound evaluations were done on a daily basis, considering that variations of the time of ovulation and fertilization may occur among animals. Moreover, embryos were detected in all mares that showed irregularities on the dorsal region of the vesicle at 25 days of gestation, which developed normally on the subsequent examinations.

On the following ultrasound evaluations, between 25 and 60 days of pregnancy, the developmental pattern of the conceptus, including allantoic sac development, yolk sac regression and umbilical cord formation, was similar to that described for mated or inseminated pregnant mares
(GINTHER, 1992; 1998), jennies (MEIRA et al., 1998) and mule embryos (PAOLUCCI et al., 2012).

The reduction on the embryonic vesicle growth observed between 20 and 30 days of gestation was similar to that observed by GINTHER (1995) in mated or inseminated pregnant mares. The same growth reduction was found in embryonic vesicles of jennies (MEIRA et al., 1998) and mule embryos (PAOLUCCI et al., 2012), and is attributed to the increased uterine tone which limits the vesicle expansion on a cross-sectional view by ultrasonography (GINTHER, 1995). Thus, the embryonic growth profile is similar in early pregnancies of cyclic and non-cyclic pregnant mares, jennies and pregnancies carrying mule embryos.

The similar growth of the embryonic vesicle between the corresponding days of gestation in Altrenogest and Control groups are in agreement with the findings of VOLLER et al. (1991). These authors found no difference on the embryonic vesicle growth average from 10 to 50 days of pregnancy between cyclic pregnant mares treated with altrenogest until 65 days, which received PGF2 $\alpha$ on day 10 after ovulation to destroy the primary corpus luteum, and non-treated cyclic mares which did not receive a PGF2 $\alpha$ injection.

The embryo proper/fetus development was also similar between groups during all evaluated days of pregnancy. It is worth noting that WILLMANN et al. (2011) investigated the effect of altrenogest treatment on the conceptus development of pregnant mares containing primary corpus luteum and observed an improvement on embryonic/fetal growth in treated mares older than eight years between 30 to 45 days of gestation. The authors suggested that the altrenogest supplementation may facilitate the increase in growth factors expression in older mares. However, this effect was not observed beyond day 40, when an increment on progesterone concentration secreted by the SCL was detected, regardless of altrenogest treatment and age of the mares.

In the present study, a positive effect of altrenogest on embryonic/fetal development was not detected in non-cyclic mares, with absence of a primary corpus luteum. In addition, a significant effect on fetus development was also not observed in those mares that developed SCL between 40 and 60 days of pregnancy, thereby increasing progesterone concentration, as reported by WILLMANN et al. (2011). Additional studies describing the endogenous and exogenous progesterone concentrations are necessary to elucidate the effect of total progesterone concentration on conceptus development. 


\section{CONCLUSION}

In conclusion, this study demonstrates that conceptus development between 15 and 60 days of gestation in non-cyclic progestin treated mares is similar to that of cyclic ones, indicating that the uterine environment of non-cyclic mares treated with altrenogest provides similar conditions for the development of transferred embryos.

\section{ACKNOWLEDGMENTS}

The authors thank Fundação de Amparo à Pesquisa do Estado de São Paulo (FAPESP) for the financial support and also thank Fazenda São Sebastião and José Dell'Aqua Junior for providing the mares for this study.

\section{BIOETHICS AND BIOSECURITY COMMITTEE APPROVAL}

This experiment was approved by the Ethics Committee on Animal Use of the School of Veterinary Medicine and Animal Science - UNESP - Botucatu (CEUA - \#115/2009).

\section{REFERENCES}

BALL, BA. Embryonic loss in mares: incidence, possible causes, and diagnostic considerations. Veterinary Clinics of North America: Equine Practice, v.4, n.2, p.263-290, 1988.

BETTERIDGE, K.J. The structure and function of the equine capsule in relation to embryo manipulation and transfer. Equine Veterinary Journal, v.21, p.92-100, 1989. Available from: <http://onlinelibrary. wiley.com/doi/10.1111/j.2042-3306.1989.tb04690.x/pdf>. Accessed: Feb. 14, 2014. doi: 10.1111/j.2042-3306.1989.tb04690.x.

CARNEVALE,E.M. etal. Factorsaffecting pregnancy rates andearly embryonic death after equine embryo transfer. Theriogenology, v.54, p.965-979, 2000. Available from: <http://www.sciencedirect. com/science/article/pii/S0093691X00004052>. Accessed: Feb. 13, 2014. doi: 10.1016/S0093-691X(00)00405-2.

GASTAL, M.O. et al. Effect of oxytocin, prostaglandin F2alpha, and clenbuterol on uterine dynamics in mares. Theriogenology, v.50, p.521-534, 1998. Available from: <http://www.sciencedirect. com/science/article/pii/S0093691X98001587>. Accessed: Feb. 14, 2014. doi:10.1016/S0093-691X(98)00158-7.

GINTHER, O.J.Fixation and orientation of the early equine conceptus. Theriogenology, v.19, p.613-623, 1983. Available from: <http:// www.sciencedirect.com/science/article/pii/0093691X83901814>. Accessed: Feb. 14, 2014. doi: 10.1016/0093-691X(83)90181-4.

GINTHER, O.J. Reproductive biology of the mare: basic and applied aspects. 2.ed. Cross Plains WI: Equiservices, 1992. 642p.

GINTHER, O.J. Ultrasonic imaging and animal reproduction: horses, book 2. Cross Plains WI: Equiservices, 1995. 400p.

GINTHER, O.J. Equine pregnancy: physical interactions between the uterus and conceptus. American Association of Equine
Practitioners Proceedings, v.44, p.73-104, 1998. Available from: $<$ http://www.produccionbovina.com.ar/produccion_equinos/ curso_equinos_I/16-ginther.pdf>. Accessed: Feb. 14, 2014.

GRECO, G.M. et al. Use of long acting progesterone to acyclic embryo recipient mares. Revista Brasileira de Zootecnia, v.41, n.3, p.607-611, 2012. Available from: <http://www.scielo.br/ scielo.php?script=sci_arttext\&pid=S1516-35982012000300019>. Accessed:Feb. 13,2014. doi: 10.1590/S1516-35982012000300019.

MCKINNON, A.O. et al. Ovariectomized steroid-treated mares as embryo transfer recipient and as a model to study the role of progestins in pregnancy maintenance. Theriogenology, v.29, p.1055-1063, 1988.

MEIRA, C. et al. Ultrasonographic evaluation of the conceptus from days 10 to 60 of pregnancy in jennies. Theriogenology, v.49, p.14751482, 1998. Available from: <http://www.theriojournal.com/article/ S0093-691X(98)00093-4/pdf>. Accessed: Mar. 11, 2014.

PAOLUCCI, M. et al. Ultrasonographic features of the mule embryo, fetus and fetal-placental unit. Theriogenology, v.77, p.240-252, 2012. Available from: $<$ http://www.theriojournal.com/ article/S0093-691X(11)00377-3/fulltext>. Accessed: Mar. 11, 2014. doi: 10.1016/j.theriogenology.2011.07.030

ROCHA-FILHO, A.N. et al. Transfer of equine embryos into anovulatory recipients supplemented with short or long acting progesterone. Animal Reproduction, v.1, n.1, p.91-95, 2004. Available from: <http://www.cbra.org.br/pages/publicacoes/ animalreproduction/issues/download/AR001.pdf $>$. Accessed: Feb. 13, 2014.

SAS INSTITUTE. SAS/STAT 9.2 User's guide. 2.ed. Cary, NC, 2009. 238p.

SILVA, L.A.; GINTHER, O.J. An early endometrial vascular indicator of completed orientation of the embryo and the role of dorsal endometrial encroachment in mares. Biology of Reproduction, v.74, p.337-343, 2006. Available from: <http:// www.biolreprod.org/content/74/2/337.long $>$. Accessed: Feb. 13, 2014. doi: 10.1095/biolreprod.105.047621.

SILVA, E.S.M. et al. Supplementary corpora lutea monitoring allows progestin treatment interruption on day 70 of pregnancy in non-cyclic recipient mares. Animal Reproduction Science, v.144, p.122-128, 2014. Available from: <http://www. animalreproductionscience.com/article/S0378-4320(13)003515/fulltext $>$. Accessed: Jan. 10, 2014. doi: 10.1016/j. anireprosci.2013.12.004

VANDERWALL, D.K. Early embryonic loss in the mare. Journal of Equine Veterinary Science, v.28, n.11, p.691-702, 2008.

VOLLER, B.E. et al. The effect of Regu-Mate, a synthetic progestin, on early pregnancy maintenance, conceptus growth, and corpora lutea development in pregnant pony mares. Equine Nutrition and Physiology Society (Refereed Papers from the 11 $^{\text {th }}$ Symposium), v.11, n.1, p.46-50, 1991

WILLMANN, C. et al. Effects of age and altrenogest treatment on conceptus development and secretion of $\mathrm{LH}$, progesterone and eCG in early- pregnant mares. Theriogenology, v.75, p.425-428, 2011. Available from: <http://www.theriojournal.com/article/ S0093-691X(10)00263-3/fulltext>. Accessed: Feb. 15, 2014. doi: 10.1016/j.theriogenology.2010.05.009. 